\section{Prognostic value of urinary albumin concentration in diabetic patients surviving the first 5 years after assessment}

Dear Sir,

Damsgaard et al. [1] suggest that urinary albumin excretion rate is a short-term predictor of mortality which is of no prognostic value after 5 years follow-up. We have examined this hypothesis in a population-based cohort of 236 non-insulin-dependent diabetic patients. Details of the cohort have previously been published elsewhere [2] and, over a period of 7-8 years during which 87 deaths occurred, an elevated random daytime urinary albumin concentration (UAC $40-200 \mathrm{mg} /$ ) was a strong independent predictor of mortality. We have extended the follow-up period up to 31 December 1992 to include a total of 128 deaths, and now report the effect of removing from the analysis all the patients who died during the first 5 years follow-up.

An age-stratified log rank test was performed to assess the association between each variable and survival for the extended follow-up period. After a median follow-up period of 9.4 years, significant predictors of mortality were duration of diabetes $(p=0.026), \mathrm{HbA}_{1}(p=0.006)$, intermittent claudication $(p=0.017)$, lens opacity $(p<0.001)$, more severe retinopathy defined as $\geq$ grade $\mathbf{B}$ of the Hammersmith grading system [3] $(p<0.001)$, UAC $(p=0.003)$, and type of treatment $(p=0.007)$. A step-wise Cox regression forward selection procedure was performed to identify all significant prognostic variables at the $5 \%$ level of significance for inclusion in the model. Age, duration of diabetes, $\mathrm{HbA}_{1}$, lens opacity, more severe retinopathy, and UAC were found to be significant independent predictors of early mortality (Table 1 ). Other model selection procedures were explored and confirmed the robustness of the model. With increasing follow-up there was, however, evidence of a decline in the proportional hazard for lens opacity, but a Cox analysis stratified by lens opacity showed no material change in the coefficients for the other factors in the model.

Corresponding author: Dr. H. A. W. Neil, Department of Public Health and Primary Care, University of Oxford Gibson Building, Radcliffe Infirmary, Oxford OX2 6HE, UK
After removing all patients who did not survive the first 5 years, among the remaining 184 patients there were 65 deaths. An age-stratified $\log$ rank test demonstrated that $\mathrm{HbA}_{1}(p=0.014)$, more severe retinopathy $(p=0.001)$, UAC $(p=0.023)$, and type of treatment $(p=0.063)$ were of borderline or conventional statistical significance as predictors of mortality. A step-wise Cox regression forward selection procedure identified age, $\mathrm{HbA}_{1}$, and more severe retinopathy to be

Table 1. Predictors of all-causes mortality estimated by the Cox-proportional hazards model for the whole study period and after excluding patients who died during the first 5 years follow-up

\begin{tabular}{|c|c|c|c|c|}
\hline & \multicolumn{2}{|c|}{$\begin{array}{l}\text { Whole study } \\
\text { period }\end{array}$} & \multicolumn{2}{|c|}{$\begin{array}{l}\text { Excluding deaths in } \\
\text { first } 5 \text { years follow-up }\end{array}$} \\
\hline & $\begin{array}{l}\text { Hazard } \\
\text { ratio }\end{array}$ & $95 \% \mathrm{CI}$ & $\begin{array}{l}\text { Hazard } \\
\text { ratio }\end{array}$ & $95 \%$ CI \\
\hline $\begin{array}{l}\text { Age (years) } \\
59-68 \\
69-74 \\
\geq 75\end{array}$ & $\begin{array}{r}1.84 \\
5.33 \\
11.79\end{array}$ & $\begin{array}{l}0.78-4.32 \\
2.44-11.64 \\
5.32-26.11\end{array}$ & $\begin{array}{r}2.02 \\
5.20 \\
15.19\end{array}$ & $\begin{array}{l}0.79-5.13 \\
2.19-12.39 \\
6.07-38.03\end{array}$ \\
\hline $\begin{array}{l}\text { Diabetes dur } \\
4-7 \\
8-12 \\
\geq 13\end{array}$ & $\begin{array}{c}\text { ion (year } \\
1.13 \\
0.96 \\
1.79\end{array}$ & $\begin{array}{l}0.64-2.00 \\
0.55-1.67 \\
1.05-3.05\end{array}$ & & \\
\hline $\begin{array}{c}\mathrm{HbA}_{1}(\%) \\
8.6-9.9 \\
10.0-12.0 \\
\geq 12.1\end{array}$ & $\begin{array}{l}1.66 \\
1.08 \\
2.30\end{array}$ & $\begin{array}{l}0.95-2.93 \\
0.60-1.95 \\
1.29-4.08\end{array}$ & $\begin{array}{l}2.31 \\
1.93 \\
3.46\end{array}$ & $\begin{array}{l}1.00-5.30 \\
0.87-4.29 \\
1.52-7.89\end{array}$ \\
\hline Lens opacity & 1.85 & $1.25-2.76$ & & \\
\hline $\begin{array}{l}\text { Retinopathy } \\
<\text { Grade B } \\
\geq \text { Grade B }\end{array}$ & $\begin{array}{l}0.87 \\
2.98\end{array}$ & $\begin{array}{l}0.49-1.56 \\
1.72-5.18\end{array}$ & $\begin{array}{l}1.06 \\
3.48\end{array}$ & $\begin{array}{l}0.48-2.33 \\
1.46-8.29\end{array}$ \\
\hline $\begin{array}{l}\mathrm{UAC}(\mathrm{mg} / \mathrm{l}) \\
>15-<40 \\
40-200 \\
>200\end{array}$ & $\begin{array}{l}0.80 \\
2.24 \\
1.13\end{array}$ & $\begin{array}{l}0.48-1.33 \\
1.36-3.70 \\
0.39-3.23\end{array}$ & $\begin{array}{l}0.88 \\
2.44 \\
0.88\end{array}$ & $\begin{array}{l}0.44-1.77 \\
1.17-5.09 \\
0.20-3.76\end{array}$ \\
\hline
\end{tabular}

Hazard ratio $=1.0$ for age $28-58$ years, duration of diabetes $0-3$ years, $\mathrm{HbA}_{1}<8.6 \%$, no lens opacity, no retinopathy, and $\mathrm{UAC} \leq 15 \mathrm{mg} / \mathrm{l}$ 
independent predictors of mortality, and, after multivariate adjustment for these factors, UAC was of borderline statistical significance $(p=0.070)$. Inclusion of UAC as a factor in the model (Table 1) demonstrated, however, that a UAC of 40$200 \mathrm{mg} / \mathrm{l}$ was associated with a 2.4-fold increased mortality risk.

Our results suggest that microalbuminuria is a predictor of short-term and possibly longer-term mortality. There are a number of possible explanations for the difference between our findings and those of Damsgaard et al. [1] but the inconsistency may be explained simply by the relatively small sample size of both of these cohorts. Further follow-up is required before a firm conclusion can be reached, and it is premature to conclude that microalbuminuria is a predictor of only shortterm mortality.

\section{References}

1. Damsgaard EM, Froland A, Jorgensen OD, Mogensen CE (1993) Prognostic value of urinary albumin excretion rate and other risk factors in elderly diabetic patients and nondiabetic control subjects surving the first 5 years after assessment. Diabetologia 36: 1030-1036

2. Neil A, Hawkins M, Polok M, Thorogood M, Cohen D, Mann J (1993) A prospective population-based study of microalbuminuria as a predictor of mortality in NIDDM. Diabetes Care 16: 996-1003

3. Oakley N, Hill DW, Joplin GF, Kohner EM, Fraser TR (1967) Diabetic retinopathy 1: the assessment of severity and prognosis by comparison with a set of standard fundus photographs. Diabetologia 3: 402-405

H. A. W. Neil, M.M. Hawkins, M. H.N. Potock, J. I. Mann

\section{Book review}

David E. Moller (ed) Insulin resistance. Chichester, John Wiley \& Sons, Ltd. 1993. 425 pp. (ISBN 0-471-93977-3) £ 75

Titles of books tend to evoke emotional responses. For many scientists and physicians, the term "insulin resistance" has become associated with nebulous concepts cushioned from experimental data by many assumptions. As pointed out by Alzaid and Rizza in their chapter, Harold Himsworth, the father of this field, did not like the term. He prefered to talk about the more definite quantity of insulin sensitivity to change in plasma glucose - that which is actually measured in clinical studies. Nonetheless, even he would have been proud to own a copy of this book which summarizes current knowledge of the mechanism of insulin action and the relevance to several important clinical syndromes of abnormally low insulin sensitivity.

The clarity of thought which characterises this book is evident from Chapter One in which Jeff Flier pin-points the need to specify the particular action of insulin being studied in a particular tissue. The many different actions of this hormone exhibit individual sensitivities such that relative insensitivity to stimulation of glycogen synthesis, for example, may not be reflected by corresponding change in inhibition of lipolysis. Conclusions from one tissue may not be extrapolated to other tissues. Maurice White and Ron Kahn provide an excellent perspective on the development of knowledge about the insulin receptor kinase and insulin receptor substrate 1 . Moving further into the cell, they go on to cut a swathe of understanding through the complexities of the other players in the intracellular hierarchy.
The clinician glancing through the book would stop first at the chapter by David Moller and Steve O'Rahilly. Could it be that syndromes of severe insulin insensitivity are missed in busy, everyday practice? The descriptions of these syndromes with the accompanying pictures make essential reading for all specialists in internal medicine. Other chapters on clinical topics include those on the polycystic ovarian syndrome, hypertension, atherosclerosis and non-insulin-dependent diabetes. The latter is worthy of special mention, providing as it does a thoughtful and complete discussion of factors which may underlie the observed low insulin sensitivity of glucose and lipid metabolism in non-insulin-dependent diabetes. In the chapter on therapeutic approaches, no new messages could be conveyed. Discussion of many therapeutic non-starters was included with only a bare outline of the hopeful thiozolidinedione agents.

A gripping account of the private life of the insulin receptor is provided by Simeon Taylor and David Moller. They also describe the five major classes of mutant defects in insulin receptor physiology, from impaired intracellular transport to abnormal folding on the cell surface. The revealed complexities are telling. Some siblings with the same insulin receptor mutation $\left(\mathrm{Val}^{382}\right.$ ) exhibit different clinical syndromes, demonstrating that even with knowledge of a precise major mutation polygenic modulating factors still have to be evoked to explain disease.

The book is well referenced, well presented and adequately sprinkled with diagrams and figures. All interested in clinical diabetes, insulin action or cell biology should have a copy on the shelf. Their other copy should be on loan to a research student.

Roy Taylor 